The BDJ News section accepts items that include general news, latest research and diary events that interest our readers. Press releases or articles may be edited, and should include a colour photograph if possible. Please direct your correspondence to the News Editor, Arveen Bajaj at the BDJ, The Macmillan Building, 4 Crinan Street, London N19XW or by email to bdj@bda.org

\title{
Preventive dentistry prize awarded
}

John Edwards BDS recently won the 2004 Dentsply/Cordent Trust VDP Award for Preventive Dentistry. Dr Edward created a practice leaflet for children, explaining some of the treatments available and the benefits of regular visits to the dentist, which is designed to be read to a child by a parent, or read by the child alone. The Cordent Trust is a charitable foundation dedicated to the promotion of preventive dentistry throughout the UK and worldwide. The award is decided by a panel of Cordent's board members and awarded to the VDP whose project, (as part of his or her VDP work), is judged to have the most merit in promoting prevention in practice. It includes a prize of $£ 1,000$. Pictured from left to right, are Peter Rees, General Manager of Dentsply Ltd., Dr Edwards, David Phillips OBE, Chairman of the Cordent Trust, and Meredyth Bell MBE, Hon. Secretary of the Cordent Trust.

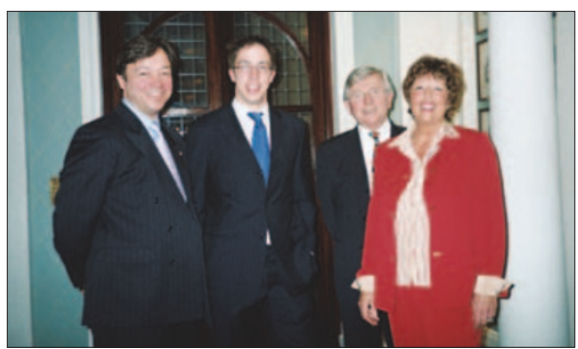

\section{New cross-border collaboration}

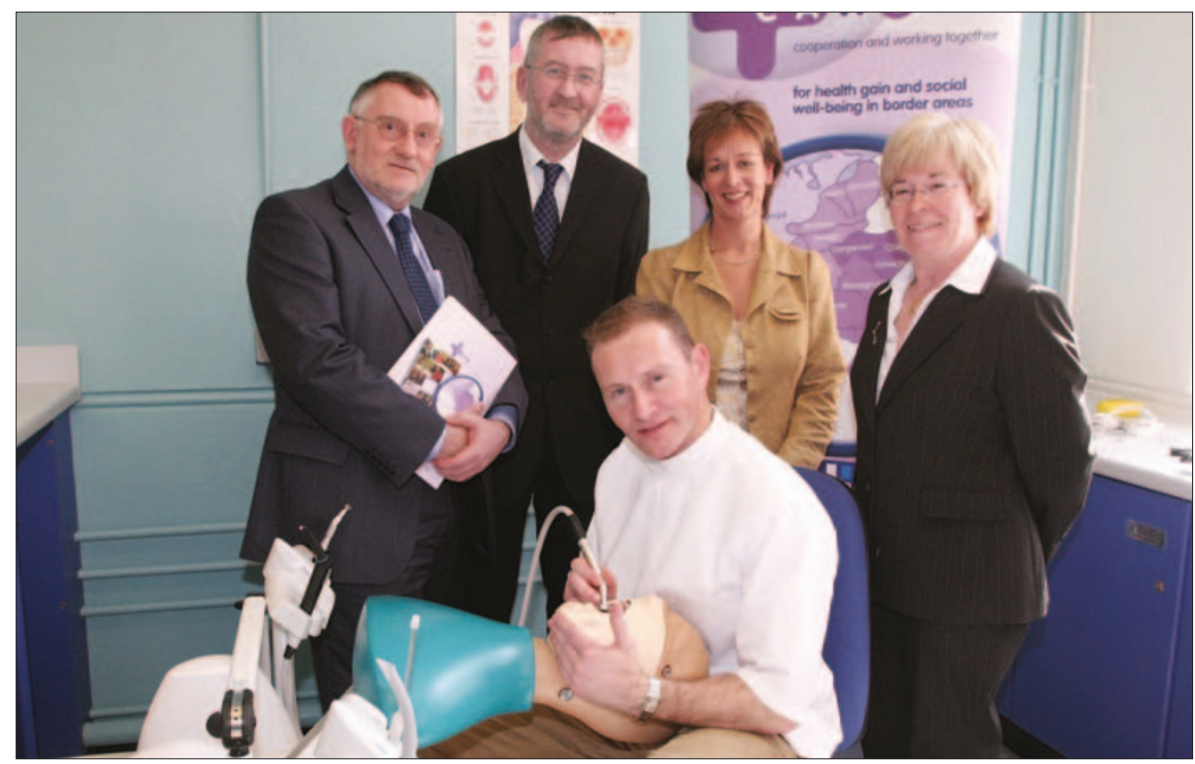

Dentists based in the border region of Ireland and Northern Ireland will now be able to access professiona training and education facilities nearer home with the opening of a unique training centre in Strabane, Co.Tyrone, Northern Ireland. The cross border Dental Outreach Skills Centre will enable clinicians to participate in undergraduate, postgraduate and professional development courses nearer to home, rather than having to travel to urban centres in Dublin, Belfast or further afield, saving hours of travelling time and thus less time lost to patient care. The innovative venture is funded by the INTERREG programme, and secured by Co-operation and Working Together (CAWT), the cross border health and social care partnership. The programme aims to address the economic and social disadvantage which can result from the existence of a border region. Dr Joe Mullen, Principal Dental Surgeon with the Health Service Executive in the North Western area of the Republic of Ireland commented, "This shared dental skills outreach centre will lead to improvements in the quality and range of dental treatment in the long term, particularly for border communities." Pictured above, left to right are Seamus Murphy, Director, North West Institute of Further and Higher Education, Jack O'Connor, Director, INTERREG, Judi McGaffin, Director of Dental Health, Western Health and Social Services Board and Frances McReynolds, Chief Officer, CAWT, and sitting, local dental surgeon, Graham Robinson.

\section{$B D J$ is the UK's top dental journal}

The British Dental Journal is the most regularly read dental publication in the UK, according to the results of an independent readership survey looking at in-depth information on the readership habits of the UK's dentists. Ten dental publications were studied, with the British Dental Association's publications, the $B D J$ and $B D A$ News consistently ranking as the top two preferred dental titles.

The survey, which was commissioned by the British Dental Trade Association, found that the $B D J$ was the most read in terms of average issue readership, the preferred read and that dentists were the most aware of it compared to other dental publications in the industry. Over $80 \%$ of dentists questioned were practice principals or an associate within a practice with an average of 20 years experience and the $B D J$ was the most read publication of those involved with decision making. Commenting on the results of the in-depth survey, $B D J$ Editor-in-Chief Stephen Hancocks said that he was delighted with the positive results for the two main BDA publications. "Our own, regular research and feedback helps guide us in terms of content, balance and value for readers but to have this verified by a completely independent source, and across the full range of UK dental publications is very encouraging," he said. "Together with our publishing partners, Nature, we will use these results constructively to continue to hone the $B D J$ and $B D A$ News to ensure that we remain in the top positions of preferred titles."

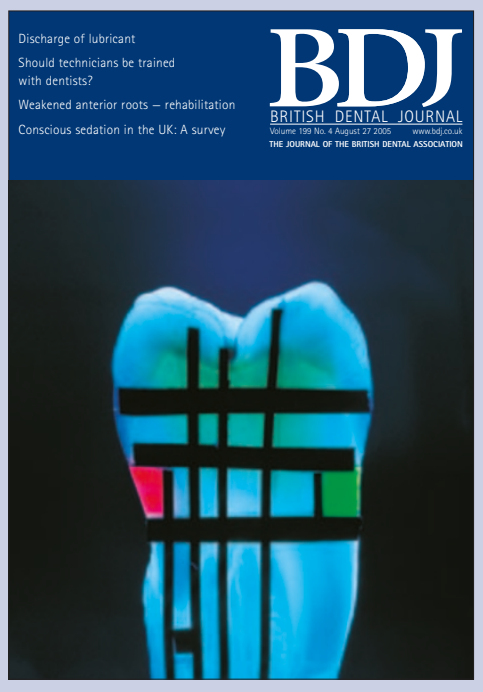




\section{DIARY}

September 2005

Oral health through public health: Professor Aubrey Sheiham, A Celebration of his work

Date: 5-6.09.05

Venue: University College London

www.ucl.ac.uk/dph

The Irish Endodontic Society 12th Biennia Congress of the European Society of

Endodontology

Date: 15-17.09.05

Venue: Dublin

Tel: +35316799144

Fax: +35316486197

www.esedublin2005.com

\section{October 2005}

BDA Metropolitan Branch: Spot the

Composite

Date: 01.10.05

Venue: British Dental Association, London

Tel: 01943604400

146th American Dental Association Annual Session and Technical Exhibition

Date: 06-09.10.05

Venue: Pennsylvania Convention Center, Philadelphia

Email: annualsession@ada.org

www.ada.org

\section{DenTech China 2005}

Date: 26-29.10.05

Venue: Shanghai Everbright Convention \&t Exhibition Center, Shanghai

Tel: 86-21-6294 6966

Fax: 86-21-6280 0908

Email:mail@showstar.net

www.dentech.com.cn

British Dental Trade Association

International Dental Showcase 2005

Date: 06-08.10.05

Venue: NEC Birmingham

Tel: 08702413365

www.dentalshowcase.com

\section{November 2005}

2nd European Congress on the

Reconstruction of the Periodontally

Diseased Patient

Date: 25-27.11.05

Venue: Radisson SAS Scandinavia Hotel, Copenhagen

Email: kongress@quintessenz.de

www.quintessenz.de/ecrp

Greater New York Dental Meeting

Date: $25-30.11 .05$

Venue: New York

Email:info@gnydm.com

www.gnydm.com

\section{Students' success recognised}

The Maurice Wohl General Dental Practice Centre recently celebrated another year's success by awarding prizes for excellence to four final year students Mr Gurpreet Singh was winner of the Maurice Wohl GDP Centre Annual Award 2005 while joint winners of the Maurice Wohl GDP Centre Certificate of Merit 2005 were Miss Rhiannon Dunbar, Mr Iain Leighton-Scott and Mr Benjamin Middleton.

The prizes are awarded to students who fulfil the highest standards in all aspects of the Centre's teaching including treatment planning and supporting clinical proficiencies, personal inter-relationship skills with staff and patients, effective team facilitation including close support four-handed dentistry and professional attitude and outlook. The final selection of winners was decided upon by dental nurses, senior staff and the director, Brian Davies.

The Maurice Wohl GDP Centre is part of the Department of Primary Care Dentistry at the GKT Dental Institute where final year students work in an adult general practice environment to perfect their clinical skills and learn successful team work and aspects of practice management. Students have a caseload of adult patients and work in conjunction with qualified and trainee dental nurses in each of the Centre's

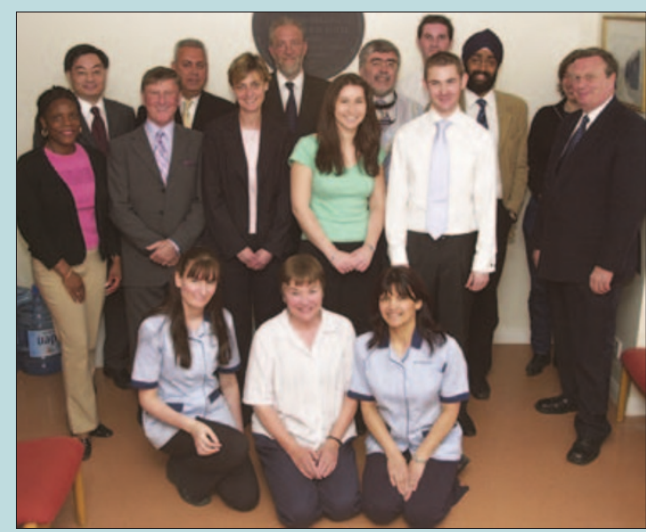
eight surgeries under the supervision of an experienced dental practitioner. Pictured: $\mathrm{Mr}$ Gurpreet Singh, (back row, second from right) winner of the Maurice Wohl GDP Centre Annual Award 2005, with joint winners of the Maurice Wohl GDP Centre Certificate of Merit 2005 Benjamin Middleton, (back row, third from right) Rhiannon Dunbar (second row, third from right) and Iain Leighton-Scott (second row second from right) together with the GDP centre staff.

\section{Dental checks for athletes}

Participants in the 7th National Special Olympic Games which took place in Glasgow earlier this summer took the opportunity to get their teeth checked as part of the Healthy Athlete programme which was running at the event. The programme comprised Special Smiles, Fit Feet, Healthy Hearing, Opening Eyes and Healthy Lifestyles, each organised by an individual clinical director.

Over a thousand athletes attended Special Smiles which was headed up by Dr M Petrina Sweeney, of the University of Glasgow Dental School. The team of dedicated dental volunteers included 25 dentists and 16 PCDs from Scotland and the rest of the UK, together with dental students from both Scottish dental schools.

Each athlete underwent an oral examination, participated in oral health instruction using a variety of oral health aids, and received a dental goody bag. A number of the athletes also gave taped interviews describing their experiences of dentistry, most of which were extremely positive.

Around two and a half thousand athletes aged from 6 to 60 with a learning disability took part in this year's games which are held every four years.

Athletes competed in 23 sports including first time sports of judo, kayaking and a motorised activity training programme.

The team of volunteers at the event

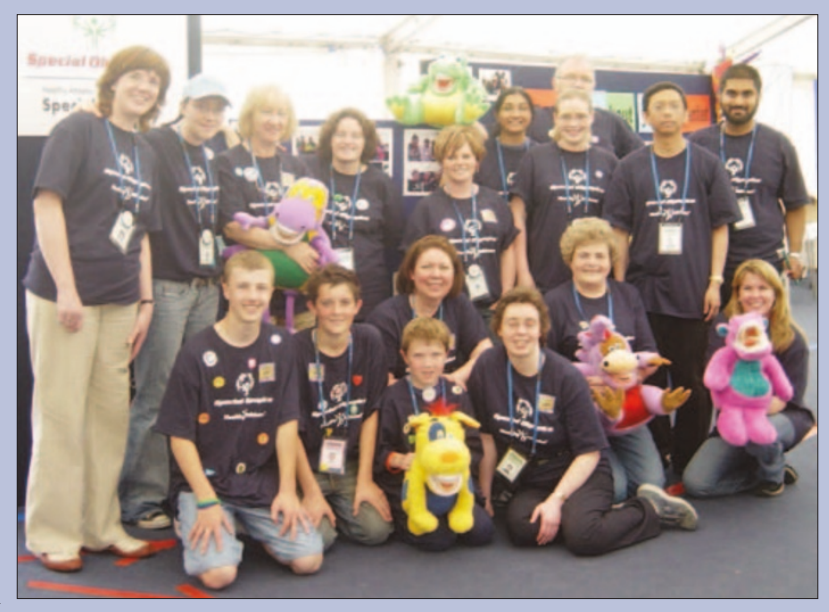




\section{Odour-eating bacteria isolated}

Researchers from Kings College have isolated bacteria which can grow on and 'mop up' smelly compounds in the mouth that are linked to bad breath. The smelly, highly reactive 'one-carbon' compounds are naturally produced from the breakdown of sulphurcontaining amino acids in the mouth.

Dr Ann Wood and her colleagues, who reported the findings in the August issue of Environmental Microbiology, isolated the odour-eating methylotrophic bacteria from the tongue, tooth plaques (supra-gingival plaques) and gum edge (sub-gingival plaques) of volunteers.

They included strains of bacillus, brevibacterium casei, hyphomicrobium sulfonivorans 1 , methylobacterium, micrococcus luteus and variovorax paradoxus. The composition and function of bacterial flora of the mouth have been extensively studied in the past, but until now it was not recognised that methylotrophic bacteria are part of the normal oral microbial environment or 'microflora'.

The researchers found no difference between strains of bacteria found in the mouths of healthy volunteers and those suffering from progressive periodontitis, a condition which is often associated with bad breath. However, no assessment was made of the levels of methylotrophic bacteria present, low levels of which may be associated with bad breath.

In a previous paper, Dr Wood et al found that the foot is also a source of methylated sulphides and strains of these odour eating bacteria, including brevibacterium and methylobacterium, which are also part of the normal foot microbial flora.

It is hoped that the results of the study will assist future investigation into the detection of the levels of methylotrophic bacteria and their possible relationship with the oral concentrations of methylated sulphides, which may lead to a natural way of reducing bad breath and foot odour.
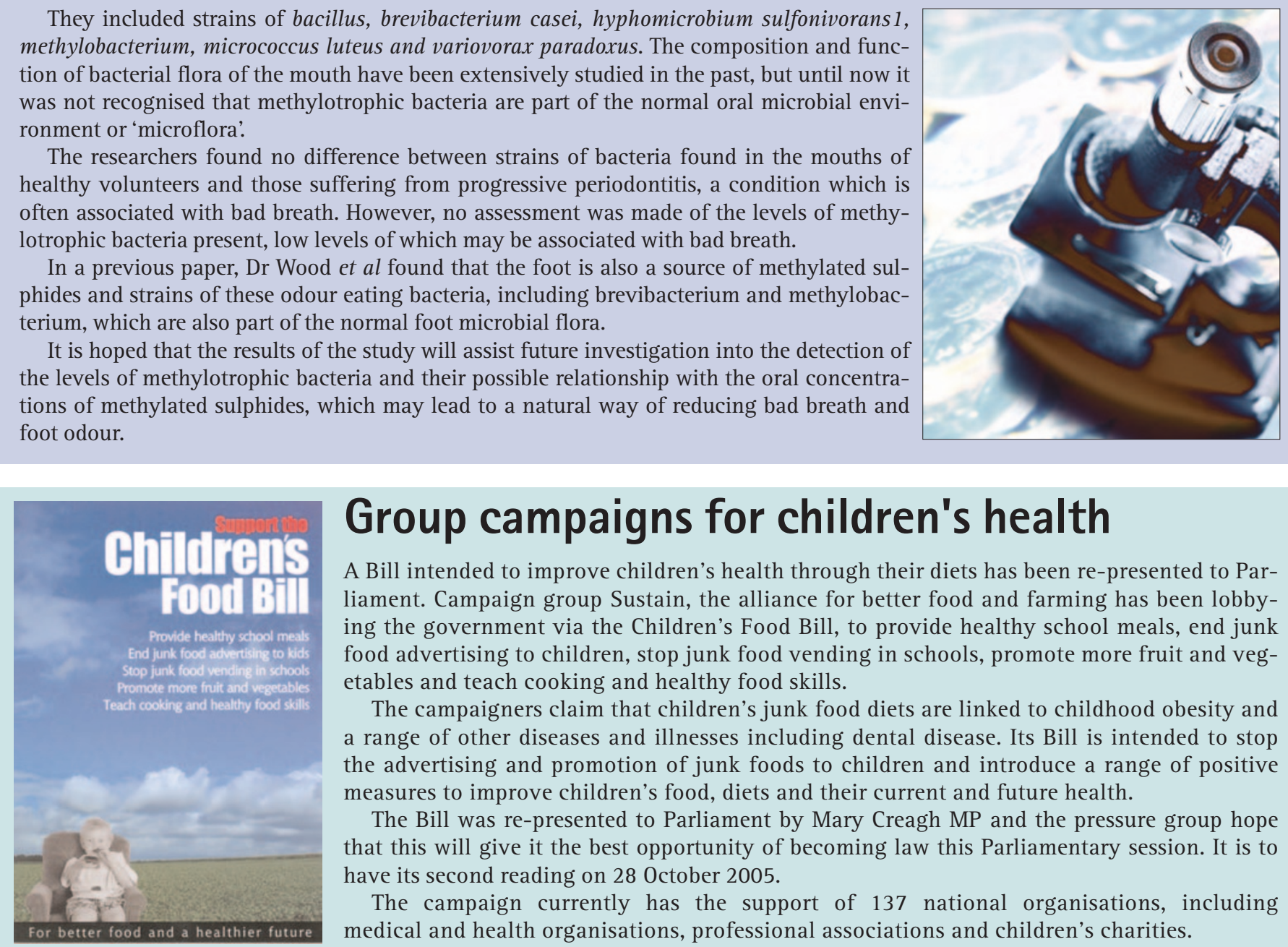

\section{Group campaigns for children's health}

A Bill intended to improve children's health through their diets has been re-presented to Parliament. Campaign group Sustain, the alliance for better food and farming has been lobbying the government via the Children's Food Bill, to provide healthy school meals, end junk food advertising to children, stop junk food vending in schools, promote more fruit and vegetables and teach cooking and healthy food skills.

The campaigners claim that children's junk food diets are linked to childhood obesity and a range of other diseases and illnesses including dental disease. Its Bill is intended to stop the advertising and promotion of junk foods to children and introduce a range of positive measures to improve children's food, diets and their current and future health.

The Bill was re-presented to Parliament by Mary Creagh MP and the pressure group hope that this will give it the best opportunity of becoming law this Parliamentary session. It is to have its second reading on 28 October 2005.

The campaign currently has the support of 137 national organisations, including medical and health organisations, professional associations and children's charities.

\section{US celebrates 60 years of water fluoridation}

The American Dental Association (ADA) and the US Public Health Service Centers for Disease Control and Prevention celebrated the 60th anniversary celebrations of water fluoridation in the United States last month.

On January 25, 1945 at 4pm, Grand Rapids, Michigan became the first city in the world to fluoridate its drinking water to prevent tooth decay. The anniversary was celebrated at the National Fluoridation Symposium in Chicago. The aim of the symposium was to recognise the impact of water fluoridation on improved oral health and, in turn, general health worldwide. The event was attended by over 200 delegates, many from outside the US.

Presentations from internationally recognised experts covered the topics of safety, benefits, cost effectiveness, and technical aspects of fluoridation, as well as the extent of fluoridation both within the US and worldwide. A presentation by University of Sheffield Professor, Mike Lennon, Chairman of the British Fluoridation Society, outlined the history and extent of water fluoridation in the UK, described the recent campaign for new legislation, and discussed recent research developments.

Around 170 million people in the US (over two-thirds of the population) receive optimally fluoridated water supplies including 43 of the 50 largest cities. Communities that have either implemented, or approved fluoridation since 1999 include Las Vegas, Los Angeles, San Antonio, San Diego, Abilene, Manchester (New Hampshire), Salt Lake County, and Palm Beach County. Many US State and city health departments are working to increase coverage to at least $75 \%$ by the year 2010 .

The ADA also launched its Professor Mike Lennon 2005 edition of Fluoridation Facts presents his symposium paper

at the symposium which is avail- Water Fluoridation in the able atwww.ada.org.

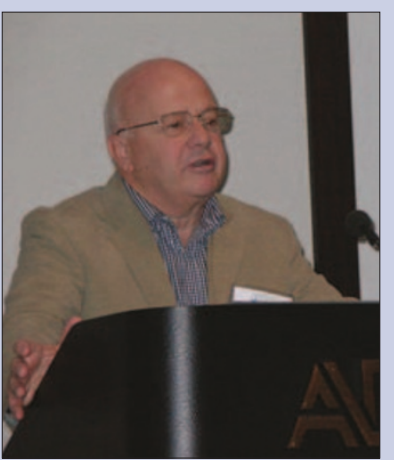
United Kingdom. 